\title{
Click erreakzioa erabiliz aktibitate biologikoa erakusten duten sistema polimerikoen garapena
}

\author{
(Azide-alkyne click reaction for developing biological activity \\ on polymeric systems and beyond)
}

\author{
Julia Sánchez-Bodón ${ }^{1}$, Isabel Moreno-Benítez ${ }^{2}$, Leyre Pérez-Álvarez ${ }^{1,3}$, \\ Leire Ruiz-Rubio ${ }^{1,3}$, José Luis Vilas-Vilela ${ }^{1,3}$ \\ ${ }^{1}$ Kimika Makromolekular taldea (LABQUIMAC), Kimika Fisikoa Saila (UPV/EHU) \\ ${ }^{2}$ Kimika Makromolekular taldea (LABQUIMAC), Kimika Organiko II Saila (UPV/EHU) \\ ${ }^{3}$ BCMaterials, Basque Centre for Materials, Applications and Nanostructures
}

LABURPENA: Azken urteetan, inplante kirurgikoak oso erabiliak bilakatu dira kaltetutako hezurrak, lotailuak edota giharrak ordezkatzeko. Hala ere, haien erabilera dela eta, ezinbestekoa da antibiotikoen tratamendua jasotzea, inplanteetan aurki daitezkeen bakterio eta beste mikroorganismoei aurre egiteko. Orokorrean, bakterioak inplanteen gainazaletan adsorbatzen dira, biofilm bat eratuz, zeinak eragiten baitu antibiotikoei erresistentzia handiagoa izatea eta baita ostalarien defentsaren babespena handitzea ere. Horren ondorioz, desiragarria da propietate antibakteriano intrintsekoa duen inplantea diseinatzea. Hala ere, batzuetan zaila da aurkitzea konposatu antibakterianoa eransteko estrategia egokia, gainazalarekin lotzeko burututako erreakzioan aktibitatea bermatzeko behar den egitura alda daitekeelako. Antibiotikoa gainazal polimeriko batean atxikitzeko ezaguna den «click» erreakzioa metodologia egokienetariko bat izan daiteke. Beraz, esan dezakegu metodologia aproposena izan daitekeela, izan ere prozedura bidez molekula organiko konplexuak materialen gainazalean lotzen dira kobalenteki. Gainera antibiotikoak biokonjugatzeko erreakzioa aurrera burutu daiteke inguru-tenperaturan, baldintza fisiologikoetan eta ura disolbatzaile gisa erabiliz etekin kuantitatiboak (ia \% 100) lortuz.

HITZ GAKOAK: polimero estaldura, propietate antibakterianoa, click erreakzioa.

ABSTRACT: In recent years, surgical implant procedures have become common strategies to restore the function of affected traumatological injuries. These implants placement requires the administration of antibiotic due to the possible presence of bacteria or other microorganism. Bacteria, normally adsorbed on the implant surface forming an adherent biofilm which exhibits increased protection from host defenses and improves resistance to antibiotic treatments. Therefore, medical devices with intrinsic antibacterial properties are highly desirable. However, the incorporation of antibiotics on the material is not easy to design due to additional structural restrictions that may compromise the bioactivity of these drugs. Thus, we considered the «click» reaction could be an excellent methodology for the conjugation of complex organic structures on the surface of many materials, since it can be carried out in water or physiological-like conditions at room temperature and product can be obtained in practically quantitative yield.

KEYWORDS: antibacterial property, click reaction, polymer coverage.

* Harremanetan jartzeko / Corresponding author: Julia Sánchez-Bodón, Kimika Makromolekular taldea (LABQUIMAC), Kimika Fisikoa Saila, Zientzia eta Teknologia Fakultatea, Euskal Herriko Unibertsitatea (UPV/EHU), Sarriena Auzoa s/n 48940, Leioa, Euskal Herria. - jsanchez903@ikasle.ehu.eus - https://orcid.org/

Nola aipatu / How to cite: Sánchez-Bodón, Julia; Moreno-Benítez, Isabe; Pérez-Álvarez, Leyre; Ruiz-Rubio, Leire; Vilas-Vilela, José Luis (2020). "Click erreakzioa erabiliz aktibitate biologikoa erakusten duten sistema polimerikoen garapena»; Ekaia, 37 , 2020, 103-116. (https://doi.org/10.1387/ekaia.20847).

Jasoa: 14 maiatza, 2019; Onartua: 19 abendua, 2019.

ISSN 0214-9001 - eISSN 2444-3255 / (c) 2020 UPV/EHU

cc)(i)(2) Obra hau Creative Commons Atribución 4.0 Internacional-en lizentziapean dago 
Julia Sánchez-Bodón, Isabel Moreno-Benítez, Leyre Pérez-Álvarez, Leire Ruiz-Rubio, José Luis Vilas-Vilela

\section{SARRERA}

Gaur egun medikuntzan burutzen diren ligamentu eta tendoi berreraikuntzak edota bestelako inplante kirurgikoak prozedura erakargarriak bilakatu dira kaltetutako artikulazioen funtzioa berreskuratzeko [1]. Mundu osoan zehar urtero milioi bat inguru aldaka-ordezkapen eta 250.000 baino gehiago belaun-ordezkapen egiten dira. Gainera, ospitalizatutako pazienteen artean \% 30ak baditu kateter baskular bat edo gehiago [2]. Hala ere, biomaterialetan, inplanteetan alegia, infekzio mikrobiala aurki dezakegun arazo larrienetarikoa da. Ezagutzen diren infekzio nosokomialen artean - osasun zentroetan har daitekeen gaixostasun infekziosoa-, erdia baino gehiago inplante-infekzioekin erlazionaturik dago; hori dela eta, urtero AEBn gutxienez milioi bat pertsona hil egiten dira infekzio nosokomialen eraginez [3]. Gainera, infekzioa desagertzeko ezagutzen den aukera bakarra inplantea ordezkatzea da.

Infekzioa inplantearen gainazalean ematen da, bakterioaren kolonizazioaren eta biofilm-aren eraketaren ondoren, eta prozesu horren lehenengo etapa bakterioaren atxikipena da [4]. Horren ondorioz, azken urteotan bakterioaren atxikipena kontrolatu edo murriztu dezaketen gainazalak diseinatu eta fabrikatu nahi izan dira. Bakterioaren gainazal-atxikipena prozesu zaila da, eta bi pauso nagusitan gertatzen da. Lehenengo pausoa oso azkarra da eta elkarrekintza itzulezina erakusten du. Bigarrena, aldiz, prozesu espezifiko eta ez-espezifikoaren artekoa da eta motela den atxikipen itzulezina erakusten du. Hori dela eta, azken hamarkadan, hiru estrategia nagusi garatu dira $[5,6]$. Lehenengo estrategian, propietate adhesio-erresistenteak dituzten gainazalak baliatzen dira. Multzo honetan, besteak beste, polietilenglikol (PEG), polietilen oxidoa (PEO) eta polibinilpirrolidina (PVP) polimeroetan orrazi moduko egiturak erabiltzen dira gainazal superhidrofiloa eta itsasgaitza sortzeko helburuarekin [7]. Gaur egun, gainazal superhidrofoboak ere aztertu dira bakterioarekiko adhesio-erresistentea bihurtu nahian [8]; hala ere, gainazal horien adhesio-erresistentziaren eraginkortasuna denborarekin murriztu egiten da molekulek edo inguruneko baldintzek eragiten duten ezegonkortasunagatik [6].

Bigarren estrategian, gainazaleko biozidaren lixibiazioa ematen da, hots, biozida gainazaletik askatzen da bakterioa hiltzeko asmoarekin. Multzo honetan, besteak beste, antibiotikoak [9] eta zilar ioiak [10], erabiltzen dira agente antibakteriano gisa, gainazaletik askatzen diren agenteak atxikipen bakterianoa murrizten baitute eta, ondorioz, infekzioa desagerrarazten da. Hala ere, antibiotikoei erresistentzia erakusten duten bakterioen kopurua handitu egin da, eta baita albo efektuak aurkezten dituzten bakterioak ere [6].

Hirugarren estrategian contact killing izenekoak baliatzen dira; izenak esaten duen moduan, gainazal mota horrek bakteria hil dezake mikroor- 
ganismoa gainazalarekin kontaktuan jartzean. Multzo honetan, gainazalak aldatzeko zenbait teknika aurkitzen dira, hala nola gainazal segregazioa, multigeruzak, self-assebly (auto-antolatze) edo grafting (txertaketa). Gainazal horietan aurki dezakegun arazo larriena hildako bakterioaren gorpua da, hau da, bakterioa hiltzean gainazalean gelditzen baita, contac killing gainazalaren eraginkortasuna murriztuz. Horretaz gain, hildako bakterioaren gorpuak erantzun immunea eta hantura eragin ditzake [6].

Azken urteotan, ikerkuntza lanen helburu nagusia gainazal bakteriorresistenteak diseinatzea da, eta horretarako estaldura polimerikoak oso erabiliak bihurtu dira. Estaldura polimeriko horiek orrazi moduko egiturak dituzte; kate polimerikoz eraikitako egitura horiek gainazal edo fasearte batean txertatuta daude grafting metodoaren bidez. Aipatutako orrazi egitura hori hartzeak kate polimerikoen propietateen aldaketa nabarmena dakar, polimero disolbatuaren edo gainazal polimeriko arrunten propietateekin alderatuz [11]. Kobalenteki lotutako orrazi egitura polimeriko horiek oso interesgarriak bilakatu dira Kimika Makromolekular arloan, batez ere, bakterioen aurkako propietateak dituztelako. Hori dela eta, gainazal solidoak eraldatzeko metodo bezala erabiltzen da hainbat aplikaziotan [12]. Propietate esanguratsuenen artean, guztiak biomedikuntzarako oso baliagarriak direnak, honako hauek nabarmentzen dira: propietate mekanikoei dagokienez nahiko egonkorrak eta gogorrak dira, hainbat talde funtzional eskuragarri dituzte kimikoki grafting metodoaren bidez eraldatuak izan daitezkeenak, eta esklusio molekularra erakusten dute, non biomolekulen eta zelulen adsortzioaren kontrako babesa eragiten duten [11]. Propietate antibakterianoei dagokienez, aurretik aipaturiko estaldura polimeriko horiek bi talde nagusitan bana daitezke: gainazal biopasiboak eta gainazal bioaktiboak [11].

\subsection{Gainazal biopasiboak}

Gainazal hauek bakterioen atxikipena murrizten dute bakterioa hil gabe [13]. Gainazal hauetan erabiltzen den prozedura ohikoena estaldura hidrofilikoa da, bio-materialaren gainazalean atxikitzen dena kobalenteki edo fisikoki. Estaldura horien ezaugarri garrantzitsuena eta landuena beren izaera ez-zikintzailea da, hau da, proteina edo bakterioa hidratatutako polimeroaren gainazalarekin kontaktuan jartzean, txertatutako kate polimerikoaren entropia konformazionala murriztu egiten da, horrek presio osmotikoa handitzea eragiten du, eta hori dela eta estaldura polimeriko hauek proteinen eta bakterioen atxikipena aldaratzen dute (1. irudia). Erabiltzen diren kate polimerikoak neutroak, kationikoak, anionikoak edota zwitterionikoak izan daitezke [11]. 
Julia Sánchez-Bodón, Isabel Moreno-Benítez, Leyre Pérez-Álvarez, Leire Ruiz-Rubio, José Luis Vilas-Vilela

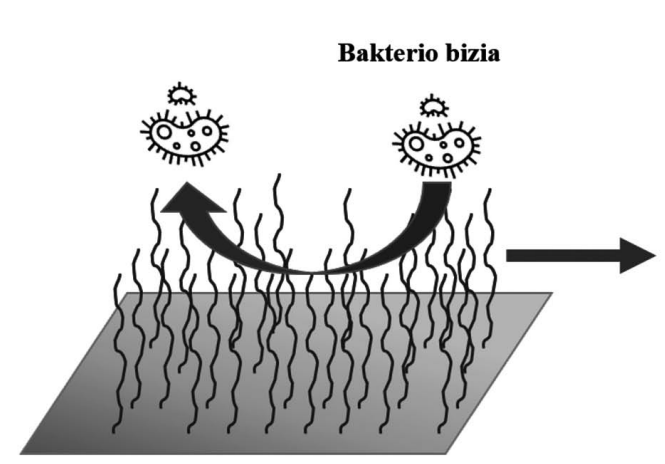

a)

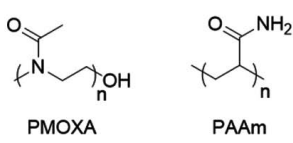

b)
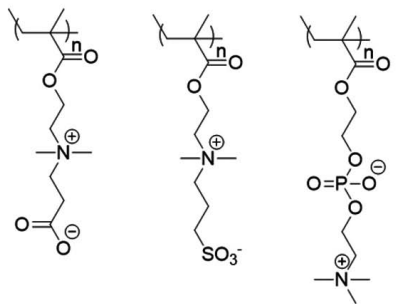

PCBMA

PSBMA

PMPC

1. irudia. Ezkerraldean gainazal batean txertatutako kate polimerikoak agertzen dira, zeinak bakterioa aldaratzen duten. Eskumaldean, erabil daitezkeen kate polimerikoak: a) polimero neutroak: PEG (polietilenglikola), PMOXA (poli-2-metil-2-oxazolina), PAAm (poliakrilamida) eta b) polimero zwitterionikoa PCBMA (polikarboxibetaina metakrilatua), PSBMA (polisulfobetaina metakrilatua), PMPC (poli(2-metakriloxometil fosforilkolina).
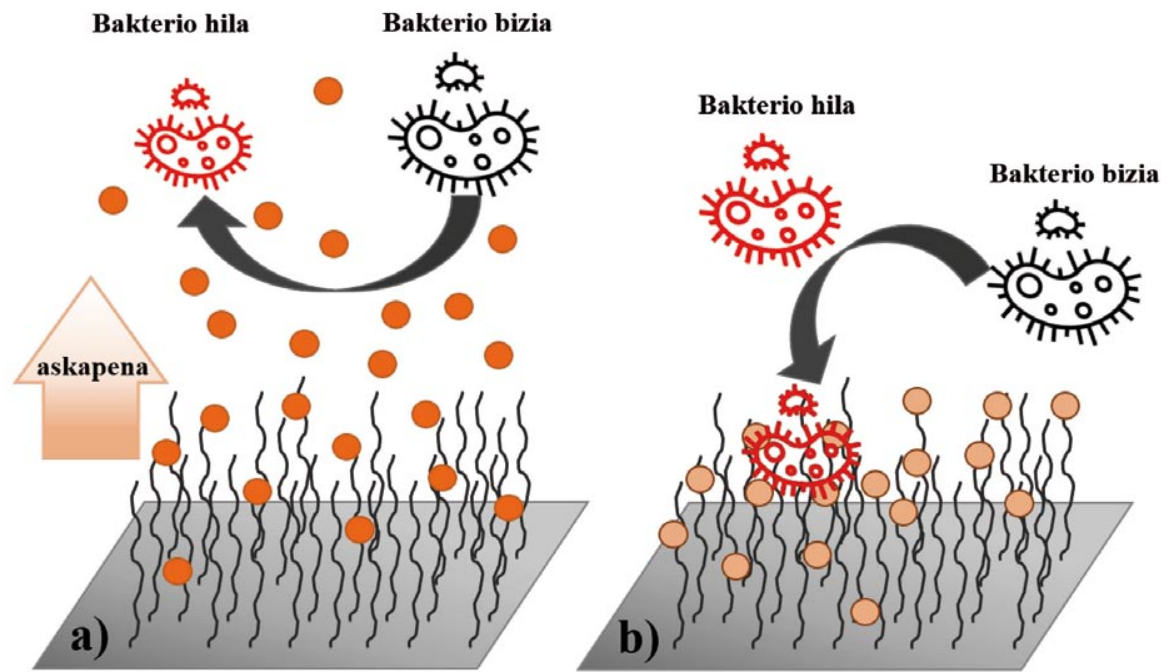

Agente antimikrobianoa

2. irudia. Agente antimikrobianoaren bi prozesuen errepresentazioa: a) askapenaren errepresentazio grafikoa eta b) agente antimikrobianoaren gainazal immobilizazioa. 


\subsection{Gainazal bioaktiboak}

Gainazal hauek bakterioak hiltzen dituen edo haien hazkuntza eteten duen agente antimikrobiano bat izaten dute. Bestalde, antibiotikoa gainazaletik askatua izan daiteke edo gainazalean immobilizatuta atxiki (2. irudia) [11].

\subsubsection{Bakterioen aurkako agente askatua}

Penizilina Fleming-en eskutik 1928. urtean aurkitu zenetik, hainbat antibiotiko mota aukeratu izan dira infekzio bakterianoa tratatzeko; baita medikuntzazko materialetan, hala nola inplanteetan aurki daitezkeen infekzioak tratatzeko ere. Hala ere, behatu egin da inplanteetan sortutako infekzioa guztiz ezabatzeko antibiotikoen tratamendua ez dela metodorik eraginkorrena; izan ere, antibiotikoak biofilm-a zeharkatzeko eta bakteriora ailegatzeko zailtasuna erakusten du. Hori dela eta biofilm-ean dagoen antibiotikoaren kontzentrazioa ez da minimora ailegatzen bakterioa hiltzeko eta, ondorioz, erresistentzia bakterianoa sortzen da. Gainera, bakterioaren metabolismoa aldatzen denez, beste antibiotikoen eraginkortasuna ere murrizten da.

70eko hamarkadan Buchhloz eta Engelbrecht ikertzaileek prozedura bat garatu zuten inplanteetan sortzen den infekzioa tratatzeko, antibiotikoak kontrolpean askatzen zituena eta gaur egun infekzioa murrizteko oso ohikoa bihurtu dena. Ikertzaile horiek polimetilmetakrilatoaren eta hezurraren arteko nahastearen barruan antibiotiko bat sartu zuten, geroago kontrolpean askatua izango zena. Hala ere, farmakoaren frakzio txiki batek baino ez ditu PMMA polimeroaren poroak zeharkatzen eta, ondorioz, infekzioa ez da guztiz desagertzen. Horretaz gain, PMMA ez da polimero biodegradagarria eta, zailtasun klinikoa sortzen duenean, beharrezkoa da bigarren ebakuntza bat burutzea, txertatutako PMMA guztia ezabatzeko hezur berria hazi baino lehen. Desabantaila hori saihestu nahian, azken hamarkadan hainbat polimero eta dispositibo biodegradagarri natural eta sintetiko garatu dira [14].

Polimero biodegradagarriek antibiotiko kantitate altuak aska ditzakete eta aurkezten dituzten propietate degradagarrien arabera hainbat aplikaziotarako baliagarriak izan daitezke, hala nola hazkuntza zelularra, ehun-birsorkuntza, farmako askapena, etab. Farmakoei dagokienez, gainazal hauek pixkanaka-pixkanaka degradatzen joaten dira antibiotikoa askatuz, antibiotikoa gainazalaren eta infekzioaren arteko faseartean geldituz. Antibiotikoa askatzen duten polimero sintetiko biodegradagarrien artean polilaktidoko-glikolido kopolimeroak dira ezagunak. Polimero naturalen artean ezagunenak kitosanoa eta kolagenoa dira; polimero horiek oso erakargarriak dira biomedikuntzan erakusten duten biobateragarritasunagatik eta hazkuntza zelularra errazteagatik; gainera, polimero merkeak eta eskuragarriak 
Julia Sánchez-Bodón, Isabel Moreno-Benítez, Leyre Pérez-Álvarez, Leire Ruiz-Rubio, José Luis Vilas-Vilela

dira [14]. Erakusten dituzten abantaila horiek guztiak direla eta gaur egun kitosanoa oso erabilgarria bihurtu da farmakoak kontrolpean askatzeko; esaterako, Bai et al. behi serum albumina farmako moduan erabili zuten kitosano hidrogelean askatuz [15].

Gentamizina, rifanpizina, minoziklina, klorohexidina, azido fusidikoa eta gisako antibiotikoak oso erabiliak dira gainazal polimerikoetan atxikitzeko [11], non bere erabilpena inplante ortopedikoak eta kateterrak diren. Antibiotiko horiek pixkanaka askatzen dira infekzio lokalak saihesteko edota tratatzeko [14].

Hala ere, bakterioen aurkako askapen horrek zenbait desabantaila aurkezten ditu: antibiotikoaren kontzentrazioa denborarekin murriztu egiten da, eraginkortasuna galduz eta, ondorioz, bakterioekiko erresistentzia sortuz.

\subsubsection{Mikrobioen aurkako agente immobilizatua}

Estrategia honetan agente antibakterianoak fisikoki edo kobalenteki immobilizatzen dira inplantearen gainazalean eta bakterioa hil egiten da harekin kontaktuan jartzean. Bakterioa hiltzeko beharrezkoa da bakterioaren mintz zelularraren apurketa gertatzea edo antibiotikoak bakterioaren mintzean elkarrekintza espezifikoa eragitea $[11,16]$.

Kasu honetan, contact killing surface brush egiturak erabili ohi dira, zeinetan pisu molekular baxuko antibiotikoak, bakteriofagoak, lisozimak, kitosanoa eta amonio kuaternariozko polimeroen atxikipena aztertu egin diren gainazal desberdinetan, gainazal bakterizida garatzeko asmoarekin [16]. In vivo eta in vitro egindako ikerkuntzen arabera, pisu molekular baxuko antibiotikoek, hala nola penizilina, bankomizina, gentamizina, materialaren gainazalean denbora luzeko atxikipena eta aktibitate antibakterianoa erakutsi dute. Horretaz gain, ehunetan farmakoak metatzea ekiditen denez, albo-efektu gutxi behatu dira. Hala ere, denborarekin bakterioarekiko erresistentzia induzitzen da. Beste agente bakteriziden kasuetan, esaterako lisotzima edo kitosanoa, gainazalean immobiliziatuak izan dira orrazi polimeriko egiturak erabiliz [11].

Agente antimikrobianoa immobilizatuta dagoen kasuan oso garrantzitsua da ezagutzea espaziatzailearen luzera eta agente antimikrobianoaren irisgarritasuna, faktore horien eragina oso garrantzitsua izaten delako mintz bakterianoarekiko elkarrekintza optimoa sortzean. Materialak erakusten dituen propietateak espaziatzailearen naturaren araberakoak izan daitezke, hala nola korrosioaren kontrako babesa, egonkortasun koloidala, labainarazte propietatea, etab.

Gaur egun agente antimikrobianoa gainazalean kobalenteki biokonjugatzeko ezagutzen diren erreakzio ohikoenetarikoak click izeneko erreak- 
zioak dira. Sharpless eta kolaboratzaileek 2001. urtean azaldutako click kimika-kontzeptua joera ikusgarrienetako bat bilakatu zen kimika sailean [17]. Kontzeptu berri horri esker erreakzio kimiko errazak, eraginkorrak, selektiboak, aldakorrak eta produktu bakarrekoak lortzen dira. Askotariko click erreakzioak ezagutzen dira, hala nola ziklo adizioak, ordezkapen nukleozaleak, C-C lotura bikoitzen gaineko adizio nukleozaleak, etab. baina horien artean azida-alkino zikloadizioa click erreakzioa ezagunena eta erabiliena bilakatu da. Hori dela eta, click kontzeptua erreakzio honetarako erabiltzen da bereziki [18] (3. irudia). Dena den, click erreakzioaren erreakzio denborak luzeak dira eta erregioselektibitatearen kontrol eza erakusten dute.

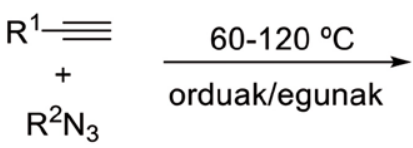

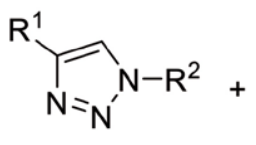

1,4-triazola<smiles>[R]c1cnnn1[R]</smiles>

1,5-triazola

3. irudia. Azida eta alkino erreaktiboen arteko click erreakzioa, 1,4- eta 1,5-triazol erregioisomeroak eskuratuz.

Azida eta alkinoaren arteko zikloadizio erreakzioan kobrea katalizatzaile gisa erabiltzerakoan, erreakzioak erakusten dituen arazoak gainditzen dira; erreakzio denbora egunetatik ordutara murriztuz eta erregioselektibitatea hobetuz, soilik 1,4 triazolak lortuz. Bestelako katalizatzaileekin, rutenioa esaterako, 1,5-triazolak lor daitezke. 1,2,3-triazolak aurkezten dituen propietate fisiko-kimiko eta biologikoei esker, lotura peptidikoaren mimetikoa den, hots, antzekotasuna duen, heterozikloa lortzen da, baina hidrolisi entzimatikoari ez aktiboa dena [18] (4. irudia). Azidak oso erreaktibo egokiak dira metodologia honetan erabiltzeko. Egia da, beste 1,3-dipolo batzuekin zikloadizioa bera azkarragoa eta selektibitate handiagokoa izan daitekeelako. Hala ere, azidek oso abantaila garrantzitsua erakusten dute: haien baldintza anitzekiko egonkortasuna, hain zuzen.<smiles>[R]NC([R])=O</smiles><smiles>[R]c1cn([R])nn1</smiles>

\section{distantzia $R^{1}-R^{2}=3,9$ A distantzia $R^{1}-R^{2}=5,0$ A}

4. irudia. Ezkerraldean, amidetan ematen den lotura peptidikoaren bi estekatzaileen arteko distantzia azaltzen da. Bestalde, eskumaldean, triazolaren loturaren distantzia bi estekatzaileen artean. 
Julia Sánchez-Bodón, Isabel Moreno-Benítez, Leyre Pérez-Álvarez, Leire Ruiz-Rubio, José Luis Vilas-Vilela

Zikloadizioan ematen den ziklo katalitikoa hurrengo eskeman laburtuta dago. Lehenengo eta behin, kobre azetiluroaren (I) eraketa ematen da. Erreakzio hori amaierako alkinoetan soilik gertatzen dela behatu da, hots, barruko alkinoekin ez da baliagarria [18]. Disolbatzaile organikoetan, hala nola azetonitriloan, beharrezkoa da konplexu horren formaziorako estekatzailearen disoziazio endotermikoa $(0.6 \mathrm{kcal} / \mathrm{mol})$. Aldiz, disoluzio urtsuetan konplexu horren formazioa exotermikoa da $(11.7 \mathrm{kcal} / \mathrm{mol})$, hots, faboratuago egonik estekatzailearen disoziazioa, erreakzioaren abiadura bizkortzen da. Horretaz gain, Density Functional Theory edota dentsitate funtzionalaren teoriaren arabera (DFT), zeina molekulen geometria eta haien loturen ezaugarriak ezagutzeko baliagarri den, behatu da alkinoaren $\mathrm{pKa}$ murriztu egiten dela kobrearekin koordinatzean, hau da, alkinoaren protoia azidoago bilakatzen da; ondorioz, disolbatzaile urtsuetan ez da beharrezkoa izango base bat erabiltzea [19]. Aldiz, bestelako disolbatzaile organikoetan, non alkinoak duen protoia ez den hain azidoa, komenigarria da base bat erabiltzea kobre eta alkinoaren arteko konplexua eratzeko. Kobre azetiluroaren formazioaren ondoren, azidan aurkitzen den estekatzaile baten desplazamendua dela eta, azida eta kobrezko azetiluro konplexua sortzen da (II). Behin konplexu hori eratuta, azidaren erreaktibotasuna handiagoa da, eta horren ondorioz hirugarren nitrogenoak eraso nukleozalea eragingo du azetiluroaren 3C-an, metaloziklo bat sortuz (III). Metaloziklo hori denborarekin eboluzionatu egiten da beste metaloziklo batera (IV) uzkurduraren ondorioz, eta azken hori protonolisi baten ondorioz nahi dugun produktua eta katalizatzailea askatzen dira ziklo katalitiko berri bat hasteko (5. irudia).

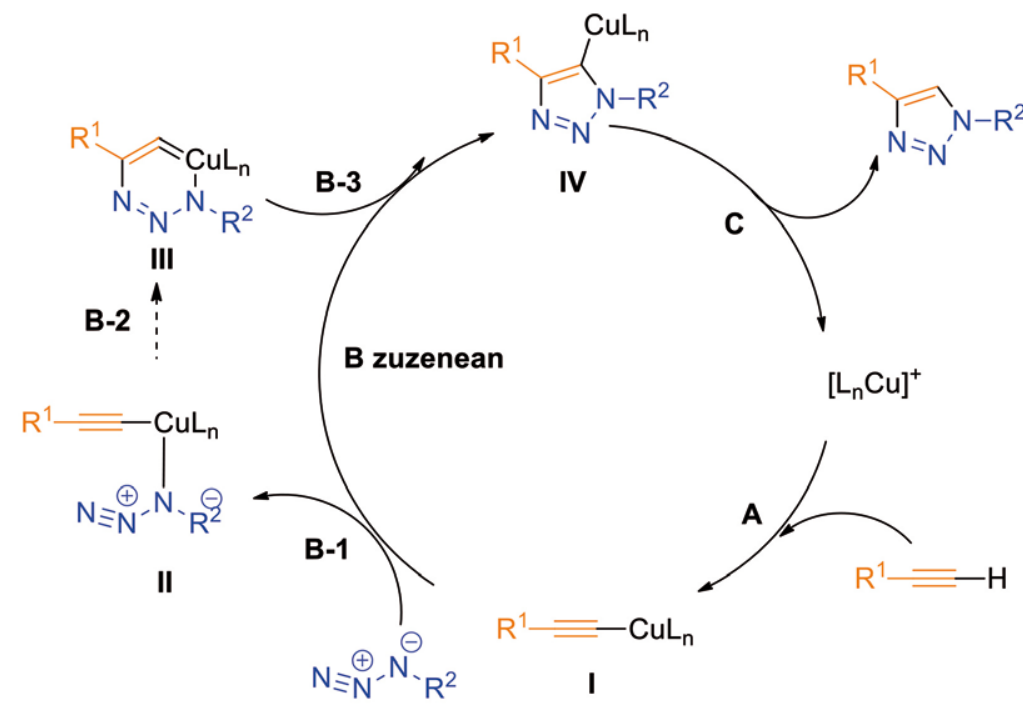

5. irudia. Kobrez katalizaturiko azida eta alkinoaren arteko click erreakzioaren ziklo katalitikoa. 
Bestaldetik, ikerlan zinetikoek kobrez katalizaturiko erreakzioa bigarren ordenakoa dela adierazten dute. Kobrearen bigarren atomoaren jokaera oraindik ez dago guztiz frogatuta, atomo horrek azida funtzioa aktiba dezake edo beste azetiluro talde batekin konplexa daiteke, horrek ziklazioaren erreaktibitatea handituko baitu [19]. Aitzitik, kobre kontzentrazioa sobera erabiltzerakoan, erreakzioaren ordena alkinoan 1 edo 2 izan daitekeela ondorioztatu da [20]. Alkinoaren kontzentrazio oso altuak erabiltzeak eragina du $\mathrm{Cu}$ (I)-ean, katalizatzailea asetuz eta zikloadizioa inhibituz. Horren ondorioz, komertzialak diren kobre azetiluro asetuek ez dute inolako aktibitate katalitikorik erakusten eta horrek frogatzen du estekatzailearen disoziazioa ziklo katalitikoan zehar oso garrantzitsua dela. Esan beharra dago ziklo katalitikoan inplikaturik dagoen I konplexuaren natura oraindik eztabaigai dela. Hala ere, horri buruzko azken ikerkuntzek ondorioztatu dute konplexu horrek bi zentro metaliko dituela, non bi estekatzaile baino gehiago inplikaturik dauden: bi alkino eta azida talde bat [20].

Azken urteotan, zikloadizioaren katalizazioa inguru tenperaturan burutu daitekeela frogatu da $\mathrm{Ru}, \mathrm{Ni}, \mathrm{Pt}, \mathrm{Pb}$ eta antzeko gatz metalikoak erabiliz. Ikerkuntza horietatik nabarmendu behar da Ru-ren erabilerak 1,5-diordezkatutako triazol aduktora eramaten duela erreakzioa; aldiz, $\mathrm{Cu}(\mathrm{I})$-katalizatzailearen erabilerarekin 1,4-diordezkatua lortzen da [19,20].

Click erreakzioaren bidez aktibitate biologikoa erakusten duten hainbat molekula atxiki izan zaizkie edonolako gainazalei. Esaterako, Aizpurua et al.-ek bankomizina izeneko antibiotikoa beirazko portari atxikitzea lortu zuten kobrez katalizaturiko click erreakzioa erabiliz. Plasma baliatuz, beirazko gainazala funtzionalizatu zuten alkino taldearekin, ondoren azidarekin eraldatutako bankomizinarekin erreakzionarazteko [21] (6. irudia).

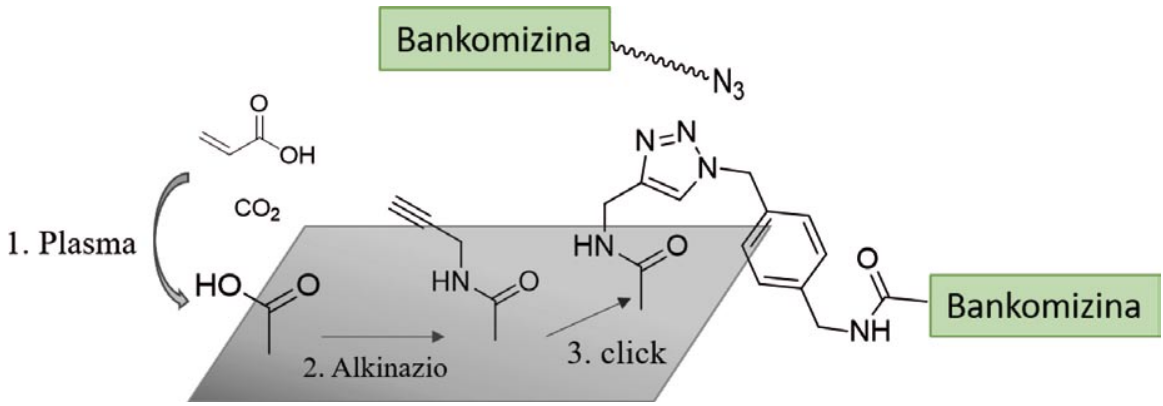

6. irudia. Plasma click erreakzioa erabiliz bankomizinaren biokonjugazioa beiran.

Bestalde, Weissleder eta kolaboratzaileek karboxilatutako dextranoa burdin oxido nanopartikula magnetikoen gainazalari atxikitzea lortu zu- 
ten click erreakzioaren bidez. Horretarako, karboxilaturiko dextranoa alkino edo azida taldeekin eraldatu ondoren, biomarkatzaile (biotina), fluoreszentzia markatzaile (indozianina, fluoreszeina), esteroide (oestrogenoa) eta farmako (paklitaxel) zenbaitekin erreakzionarazi zituzten CuAACren (Copper-Catalyzed Azide-Alkyne Cycloaddition) laguntzaz [22] (7. irudia).

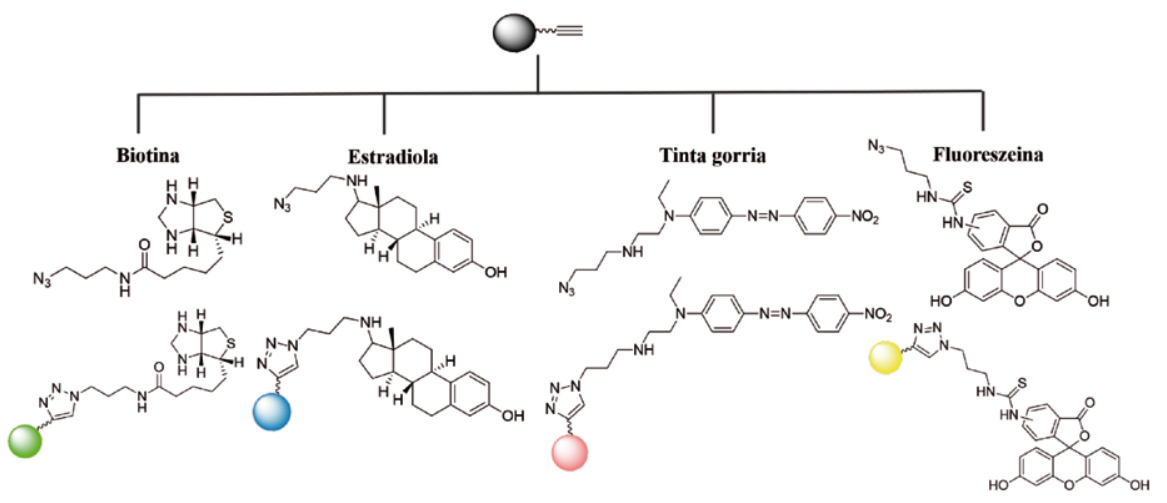

7. irudia. Click erreakzioa erabiliz aktibitate biologikoa duten burdin oxidozko nanopartikulen eraldaketen eskema.

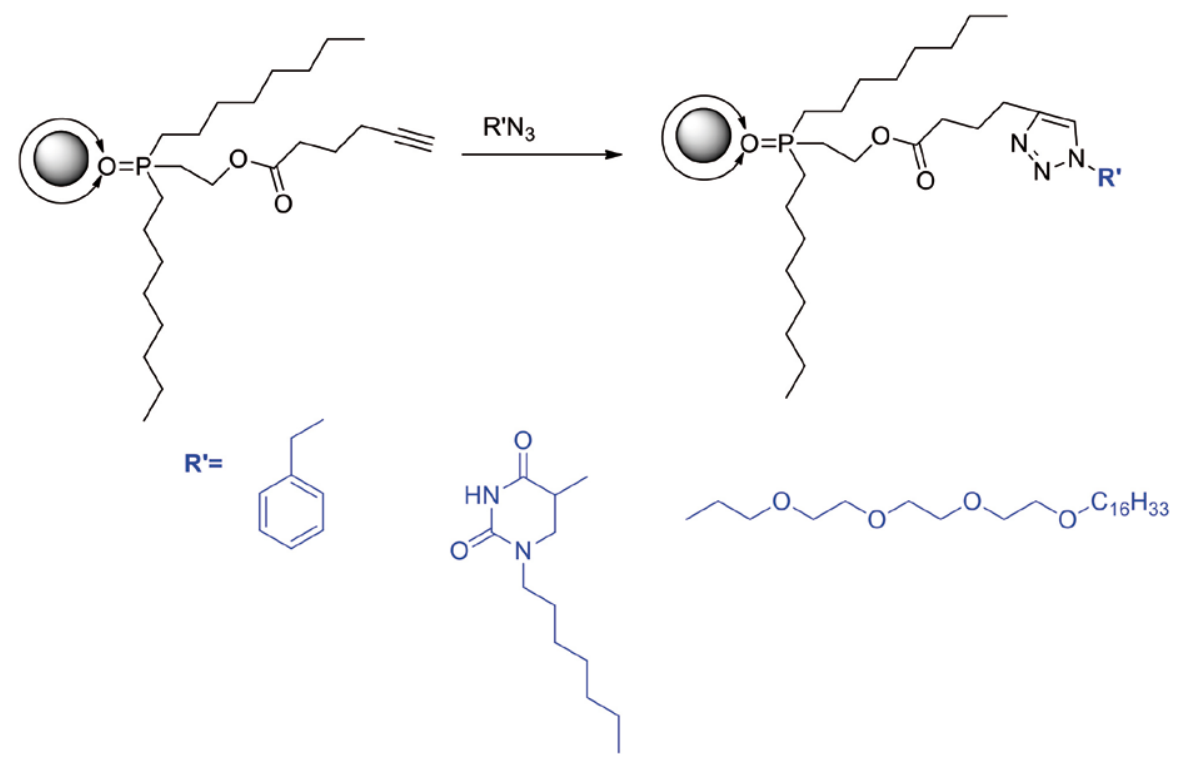

8. irudia. Click erreakzioaren bidez eraldatutako kadmio seleniuro nanopartikulak. 
Nanopartikulekin jarraituz, Binder et al.-ek kadmio seleniuro nanopartikula luminiszenteen click erreakzioa burutu zuten. CuAAC erreakzioen bidez azido barbiturikoa, timina eta oligo(etilenglikola) bezalako molekulak konjugatu ziren quantum dots nanopartikulen gainazalean (8. irudia) [23].

Wang eta kolaboratzaileek zaldien barean aurkitzen den apoferritina proteina funtzionalizatu zuten CuAACren bidez. Lehenengo eta behin, apoferritinako lisina taldeak eraldatu ziren alkino taldeekin, ondoren 3-azidakumarinarekin erreakzionarazteko (9. irudia) [24].

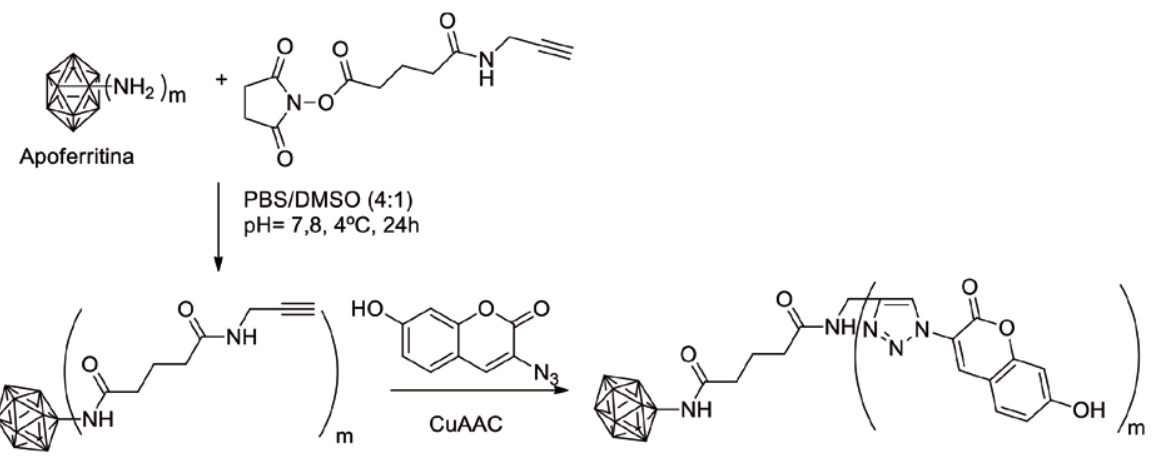

9. irudia. Click erreakzioaren bidez modifikatutako apoferritina proteina.

Beste aldetik, CuAACren bidezko proteinen funtzionalizazioen adibide esanguratsuenak Schultz eta Tirrel-en taldeen eskutik etorri ziren. Ikertzaile horiek azida taldearekin eraldatutako aminoazido ez naturalak erabili zituzten, geroago funtzionalizaturiko alkinoekin erreakzionarazteko [25]. Esaterako, Tirrel et al.-ek zelulen gainazalak eraldatu zituzten, mintzean aurkitzen ziren proteinen mutazioa eraginez, eta prozedura hori oso erabilgarria bihurtu da ugaztun zeluletan dauden zelula berriak eta zelula zaharrak desberdintzeko [26].

Beraz, laburbilduz, gainazal antibakterianoa lortzeko helburuarekin erabil daitekeen metodorik eraginkorrena antibiotikoaren immobilizazio kobalentea da. Horrela, antibiotikoaren kontzentrazioa konstante mantentzen da eta bakterioekiko erresistentzia saihesten da. Hori bai, estrategia hori proposatzen denean funtsezkoa da farmakoaren farmakoforoa, hau da, molekula batek duen funtzio taldea, zeina molekularen berezko aktibitate biologikoa ezartzen duen, ukitu gabe mantentzea, bere aktibitatea bermatzeko. Zentzu horretan, alkino eta aziden arteko click erreakzioa oso erabilgarria dela frogatu da antibiotikoak ez ezik, zenbait aktibitate biologiko dituzten molekulak ere, gainazal polimerikoetan biokonjugatzeko. 
Julia Sánchez-Bodón, Isabel Moreno-Benítez, Leyre Pérez-Álvarez, Leire Ruiz-Rubio, José Luis Vilas-Vilela

\section{ONDORIOAK}

Azida eta alkinoaren arteko zikloadizio erreakzioak ekarpen garrantzitsuak egin ditu click kimikaren arloan. Erreakzio horren potentziala dela eta oso baliagarria bihurtu da hainbat konposaturen eraikuntzan, batez ere, eskuragarri ez dauden molekula konplexuak edota heterozikloak lortzeko. Click kimikaren eragina izugarri handitzen ari da egunetik egunera, erreakzio horrek erakusten duen aldakortasunagatik eta erraztasunagatik. Gainera, lortzen den triazolaren toxizitate txikia dela eta, hainbat dira erreakzioaren erabilpenak: ez bakarrik sintesi organikoan, baizik eta materialen zientzian, polimero zientzian, biologia molekularrean edo nanoelektronikan. Hala ere, oraindik zenbait desabantaila ezagutzen dira: garrantzitsuena zitotoxizitatea erakusten duen $\mathrm{Cu}$ ioi metalikoaren erabilera baldintzatuta dago biologia arloan; izan ere, etorkizunari begira metalik gabeko metodologien garapena erronkarik erakargarrienetariko bat bilakatu da.

\section{ESKER ONAK}

Egileek sostengu ekonomikoa eskertzen dute: Eusko Jaurlaritzaren Ekonomiaren Garapena eta Azpiegituren Saila, ELKARTEK, FRONTIERS IV.

\section{BIBLIOGRAFIA}

[1] ARCIOLA, C. R.; CAMPOCCIA, D.; MONTANARO, L. 2018. «Implant infections: adhesion, biofilm formation and immune evasion». Nat. Rev. Microbiol. 16, 397-409.

[2] CAMPOCCIA, D.; MONTANARO, L.; ARCIOLA, C. R. 2006. «The significance on infection related to orthopedic devices and issues of antibiotic resistance». Biomaterials, 27, 2331-2339.

[3] NEOH, K. G.; HU, X.; ZHENG, D.; KANG, E. T. 2012. «Balancing osteoblast functions and bacterial adhesion on functionalized titanium surfaces». Biomaterials 33, 2813-2822.

[4] GUPTA, P.; SARKAR, S.; DAS, B.; BHATTACHARJEE, S.; TRIBEDI, P. 2016. «Biofilm, pathogenesis and prevention- a journey to break the wall: a review». Arch. Microbiol. 198, 1-15.

[5] LICHTER, J. A.; VAN VLIET, K. J.; RUBNER, M. F. 2009. «Design of antibacterial surfaces and interfaces: polyelectrolyte multilayers as a multifunctional platform». Macromolecules 42, 8573-8586.

[6] WANG, B. L.; REN, K. F.; CHANG, H.; WANG, J. L.; JI, J. 2013. «Construction of degradable multilayer films for enhanced antibacterial properties». ACS Applied Materials interfaces, 5, 4136-4143. 
[7] NEOH, K. G.; KANG, E. T. 2011. «Combating bacterial colonization on metals via polymer coatings: relevance to marine and medical applications». ACS Appl. Mater. Interfaces 3, 2808-2819.

[8] PERNITES, R. B.; SANTOS, C. M.; MALDONADO, M.; PONNAPATI, R. R.; RODRIGUES, D. F.; ADVINCULA, R. C. 2012. «Tunable protein and bacterial cell adsorption on colloidally templated superhydrophobic polythiophene films». Chem. Mater. 24, 870-880.

[9] SHULKA, A.; FANG, J. C; PURANAM, S.; HAMMOND, P. T. 2012. «Release of vancomycin from multilayer coated absorbent gelatin sponges». $J$. Control. Release 157, 64-71.

[10] WANG, B. L.; LIU, X. S.; JI, Y.; REN, K. F.; JI, J. 2012. «Fast and long-acting antibacterial properties of chitosan-Ag/polyvinylpyrrolidone nanocomposite films». Carbohyd. Polym. 90, 8-15.

[11] HADJESFANDIARI, N.; YU, K.; MEI, Y.; KIZHAKKEDATHU, J. N. 2014. «Polymer brush-based approaches for the development of infectionresistant surfaces». J. Mater. Chem. B. 2, 4968-4978.

[12] BARBEY, R.; LAVANANT, L.; PARIPOVIC, D.; SCHÜWER, N.; SUGNAUX, C.; TUGULU, S.; KLOK, H. 2009. «Polymer brushes via surface-initiated controlled radical polyerization: synthesis, characterization, properties, and applications». Chem. Rev. 109, 5437-5527.

[13] CHARNLEY, M.; TEXTOR, M.; ACIKGOZ, C. 2011. «Designed polymer structures with antifouling-antimicrobial properties». Reactive and Functional Polymers, 71, 329-334.

[14] ZILBERMAN, M.; ELSNER, J. J. 2008. «Antibiotic-eluting medical devices for various applications». J. Control. Release 130, 202-215.

[15] BAI, X.; BAO, Z.; BI, S.; LI, Y.; YU, X.; HU, S.; TIAN, M.; ZHANG, X.; CHENG, X.; CHEN, X. 2018. «Chitosan-based thermo/pH double sensitive hydrogel for controlled drug delivery». Macromol. Biosci. 18, 1-12.

[16] KUGEL, A.; STAFSLIEN, S.; CHISHOLM, B. J. 2011. «Antimicrobial coatings produced by «tethering» biocides to the coating matrix: A comprehensive review». Progress in Organic Coatings, 72, 222-252.

[17] CAMPOCCIA, D.; MONTANARO, L.; SPEZIALE, P.; ARCIOLA, C. R. 2010. "Antibiotic-loaded biomaterials and the risks for the spread of antibiotic resistance following their prophylactic and therapeutic clinical use». Biomaterials 31, 6363-6377.

[18] DÍAZ, D. D.; FINN, M. G.; SHARPLESS, K. B.; FOKIN, V. V .; HAWKER, C. J. 2008. «Cicloadición 1,3-dipolar de azidas y alquinos I: Principale aspectos sintéticos». An. Quim. 104, 173-180.

[19] ROSTOVTSEV, V. V.; GREEN, L. G.; FOKIN V. V.; SHARPLESS K. B. 2002. «A stepwise Huisgen cycloaddition process: Copper (I)-catalyzed regioselective "ligation" of azides and terminal alkynes». Angew. Chem. Int. Ed. 41, 2596-2599. 
Julia Sánchez-Bodón, Isabel Moreno-Benítez, Leyre Pérez-Álvarez, Leire Ruiz-Rubio, José Luis Vilas-Vilela

[20] WANG, Q.; CHAN, T. R.; HILGRAF, R.; FOKIN, V. V.; SHARPLESS, K. B.; FINN, M. G. 2003. «Bioconjugation by copper(I)-catalyzed azide-alkyne [3+2] cycloaddition». J. Am. Chem. Soc. 125, 3192-3193.

[21] BRACERAS, I.; OYARBIDE, J.; AZPIROZ, P.; BRIZ, N.; IPIÑAZAR, E.; ÁLVAREZ, N.; ATORRASAGASTI, G.; FRATILA, R. M.; AIZPURUA, J. M. 2013. «"Plasma-click" based strategy for obtaining antibacterial surfaces on implants». Plasma Process. Polym. 10, 328-335.

[22] SUN, E. Y.; JOSEPHSON, L.; WEISSLEDER, R. 2006 «"Clickable" nanoparticles for targeted imaging». Mol. Immunol.5, 122-128.

[23] BINDER, W. H.; SACHSENHOFER, R.; STRAIF, C. J. ZIRBS, R. 2007. «Surface-modified nanoparticles via thermal and $\mathrm{Cu}(\mathrm{I})$-mediated "click" chemistry: Generation of luminescent CdSe nanoparticles with polar ligands guiding supramolecular recognition». J. Mat. Chem. 17, 2125-2132.

[24] ZENG, Q.; LI, T.; CASH, B.; LI, S.; XIE, F.; WANG, Q. 2007. «Chemoselective derivatization of a bionanoparticle by click reaction and ATRP reaction». Chem. Commun. 1453-1455.

[25] LUTZ, J. F.; ZARAFSHANI, Z. 2008. «Efficient construction of therapeutics, bioconjugates, biomaterials and bioactive surfaces using azidealkyne «click» chemistry». Adv. Drug Deliv. Rev. 60, 958-970.

[26] DIETERICH, D. C.; LINK, A. J.; GRAUMANN, J.; TIRRELL, D. A.; SCHUMAN, E. M. 2006. "Selective identification of newly synthesized proteins in mammalian cells using bioorthogonal noncanonical amino acid tagging (BONCAT)». Proc. Natl, Acad. Sci. U.S.A 103, 9482-9487. 